\title{
AGILE HUMAN CAPITAL MANAGEMENT FOR FUTURE LEADER
}

\author{
Watriningsih WATRININGSIH* and Franky FRANKY \\ Universitas Prof Dr Moestopo (Beragama), Jakarta, Indonesia \\ *watri_ayu@dsn.moestopo.ac.id
}

\begin{abstract}
The prospective leaders who live in the era of Internet of Things, certainly will not experience difficulties to digital equipment. Their sufficient knowledge and skill of digital world, would become a strong foundation as a future leaders. The massive technology development, social media as one mean, has become a necessity that cannot be stopped nor avoided. This condition creates the huge and wide opportunities to enhance the credibility and competency of future leader. Recently, no one leader could move forward in their succeed without the information technology knowledge. However, those knowledge and skills will not enabling some one to automatically produce a positive and maximum performance for the organization. Hence, the agile management approach is needed to fill the gap for Z-generation to improve their performance. This paper use qualitative method through studying scientific sources such as books, journals and articles, to formulate a guideline or management concept to prepare Z-generations to face the millennium era. The research result that can be transformed for human resources management are 4 activities. They are collection (doing inventory through out topics and materials that has role to human resource quality improvement); clustering (doing identification and grouping of the inventory results with the similarities, and sort them by priority); process (doing a set of activities in cluster items that is arranged as priority set before0; and release (implementation through training for employees run by the human resource department).
\end{abstract}

Keywords: Agile Management; Internet of Things; Social Media; Z generation

\section{BACKGROUND}

Information technology, especially social media massive growth has given a noticeably impact to all human live. For example in education, business, social culture, politic and so on. Namely Facebook, Instagram, blog, twitter, YouTube, what apps, telegram, all have had changed human behavior, way or method of communication. This growth and significant and outstanding changes is beyond our imagination a few decades ago. One can be connected to hundreds, thousands, and even millions others in social media network at the same time. Hence, beyond those information sources abundances of social media there are some positive aspects and negative aspects which blended to inseparable two sides, that become a background to $\mathrm{Z}$ generation lives.

\section{Z Generation}

As the previous study that has been done, generations may be divided to six parts by its characteristic, as describe in the following table.

Table 1. Generation Categories, source: [1]

\begin{tabular}{ll}
\hline Description & Year of Birth \\
\hline Veteran Generation & $1925-1946$ \\
Baby Boomers Generation & $1946-1960$ \\
X Generation & $1960-1980$ \\
Y Generation & $1980-1995$ \\
Z Generation & $1995-2010$ \\
Alpha Generation & $2010-$ now \\
\hline
\end{tabular}

Y generation are also known as Millennial Generation [2], are known by their active contribution, sharing, seeking and content searching in social media platform both for work and recreational activity.

$\mathrm{Z}$ generation are also known as I generation; Technical generation, who are born and raised in digital world [3]. Things that distinguish them from the previous generations are their linkage and existence to those electronic equipment and digital world.

Digital world skills - social media; owned by Z generation has transformed them to be world class citizen - world citizenship; that is unlimited by time and space in communicating and interacting with others in this world. This is the new power that exist in this modern world where the world has become one language, culture and perspective - global citizenship that made of social media network. On the other hand, albeit those benefits of social media there are also negative impacts. The authors will cover both negative and positive aspects of social media in the following passage.

\section{The Positive Aspects of Social Media}

The mastery of knowledge is power. A person who master one particular scientific discipline adequately, will have more gains than others. Mastering social media will also bring some gains for some one. The social media has become an integral part in $\mathrm{Z}$ generation live [4]. Generation of which since they were born; are connected to the outstanding growth of information technology. With this huge knowledge sources, figuratively as a raw material factory - one can build about anything. The $\mathrm{Z}$ generation or millennial who receive more gains from this information technology growth especially social media [5]. With age ranging from 18 to 22, they have become avant garde to future build of a nation. Additionally informed, teenagers and young spends time approximately 8 hours a day on line. This is $1 / 3$ of their daily hours connected to world wide citizen or digital community.

The benefit of social media as summed from various sources [6]-[8], are:

1. Used as educational process.

2. Has more knowledge and educational sources.

3. Has unlimited community to exchange information beyond time and spaces limitation. 
4. Freedom to access various sources with no limitation.

5. Speed to gain source of knowledge.

6. Cheap, effective and efficient.

7. Freedom to share opinion or point of view.

8. Learn to do business.

\section{The Negative Aspects of Social Media}

As the coin with two inseparable sides, the negative side will always follows the positive side. The following passage will show those negative sides of social media [9], [10] as summed from various sources.

1. Unjustified source of knowledge.

2. The community that tends to share dangerous data and information.

3. Social media networks can take a role in someone's life.

4. Addictive.

5. Causing health problem.

6. Cyber bullying, fraud and social community outcast.

The facts proved that negative aspects mostly appear than its positive aspects in social media activity. Kidnapping, fraud, provocation and so on, has hurts the goals and important role of social media. Goons learn how to create chaos through social media has become common news. Learning to build a weapon, hurting each other, and other negative actions precisely learned from information through social media. Hence, social impact of social media always connected to negative impact instead of the positive.

The millennial generation or $\mathrm{Z}$ generation are get used to this social media implementation. Thus, social media has become "true comrade" in socializing [7], [8]. They are very familiar with this social media world. According to BBC Indonesia (January $16^{\text {th }}, 2018$ ) 3 billion people or around $40 \%$ of world population using social media. According to some reports [11], one approximately spend time 8 hours a day to share, like, write twits, and status update in social media.

Technology is a powerful and up to date device that equip $\mathrm{Z}$ generation in facing the rapidly change world. It requires a ready, fast and responsive generation to an even small changes. Hence, the technology approach and its mastery has become a must for generation who lived in the era of Internet of Things.

\section{The Internet of Things}

The IoT consists of two basic word, 'internet' and 'thing', this concept refers to the link between human and machine or machine and machine [12], [13]. The internet has become a central communication device that connects all physical forms - including human - in a virtual environment. Therefore it requires an awareness on using the IoT concept, because IoT may raise a new problem in regard to managing personal identification security, so that it will not cause new problems to human in the future [14].
Along with current development IoT has become base line of growth of business and management methodology which using this technology concept. One of them the agile methodology approach.

\section{The Agile Methodology}

The waterfall methodology is a well known and adopted in software development, whereas all system specification of a software are compiled in the beginning phase before translated into programming language instructions. When all phase is done, then the computer program is ready to use. The following figure describe the waterfall methodology [15].

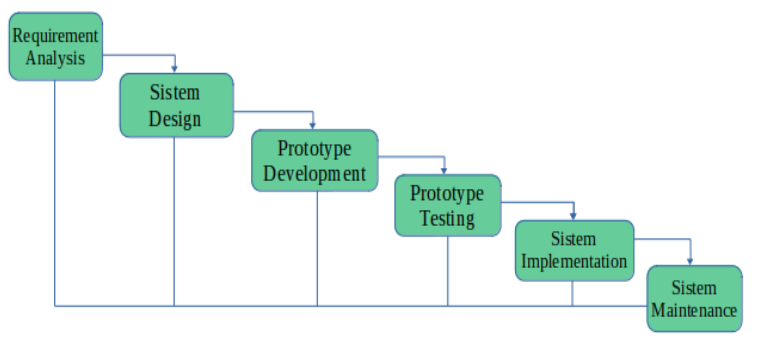

Figure 1. The Waterfall methodology in software development management

In compare to the conventional methodology above, agile methodology offers modular implementation of the software being build without finishing it $100 \%$ of all development process. This approach give specific advantages both to the end user and developer. The process in this agile methodology depicted in the following figure.

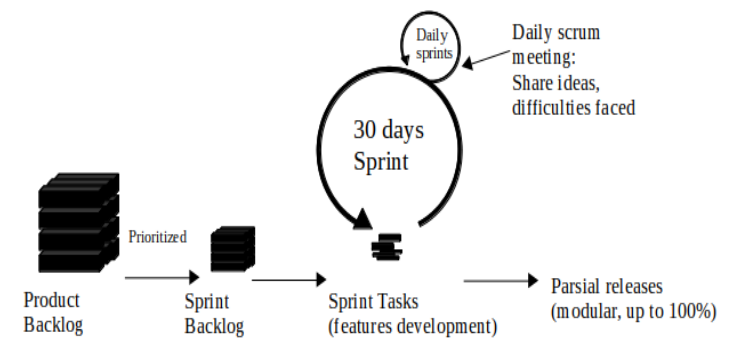

Figure 2. The Scrum Process of Agile Methodology [16], [17]

Aside from the conventional software development process, recent study shown that in Agile Methodology end user engagement is strongly involved during development phase. Hence, the IT project success rate are higher in compare to conventional methodology ie. waterfall. [15], [18].

\section{METHOD}

Literature review is used by the authors in this paper [19]. At least 3 steps are available in the road map of literature review in this paper. First, background concept. In this phase, empirical data are required in the form of written information, videos, interviews and so on, that has been validated. If required this verification must also officially legitimate by the formal institution.

Secondly, new concept. While empirical data has been gathered, the authors develop a hypothetical. The 
hypothetical based on validated data, various theoretical and from the authors scientific point of view. Third, concept implementation. During this phase, the authors will build operational steps to base the concept built earlier. A management guidance for human capital development of the future leader will be develop as the final result of this paper.

\section{Research relevance}

The agile methodology emphasize of good communication among stakeholders involved within the project, user interface designer, programmer, end user, so that the successful of software development project increased in compare to the traditional method [20]. As the opposite of the traditional process that release product after all features has been developed, the agile methodology will release the software modular, feature by feature that enabled the product to be used even when development is not reaching $100 \%$ completeness.

Further more, the agile methodology in user interface design require a bridging tools for user interface designer to be successfully released product for end user. The result is a new framework proposal that needs to be perfected in the future to be able for widen its usage in all environment or organizations [21]. Implementing agile methodology, it is suggested to do personnel choosing who will be involve in the project. A person who has intense communication skill, so its implementation will be at maximum. It is according to some observation to some of projects with similarities both the environment and the size of involved team members [22]. Lastly the agile methodology implementation has given positive impacts compared to traditional methodology. It can be proved by the distributed questionnaire results, showing the level of success implementation of agile methodology from both developer side and product owner [23].

The human resources enhancement has a close role to the economic level of a state. A sufficient education level required to improve them. By doing so, it will give a real impact to all aspect of them selves. The related study [24] has recommended that there should be a commitment from the government related to financial problem for education compared to health sectors. It requires government involvement through policies for training and education that aims to increase human capital continuity to a higher level, and also innovation capacity improvement that supports the increase of education quality starting from mid level up to the higher level education. It also suggested that government to have more commitment by supporting funds to the health sector that in the end will drive the human capital development and finally increase the living hope that become supplement to economic level. Education has a vital role in the human development, because through education can influence virtually all aspects of human being. Education is a tool for society to be inherited for generation to generation [25].

\section{Result And Discussions}

The aim of this paper is to produce a new method of human resource management by adopting process offered in agile methodology in software development projects.

In software development, agile methodology mostly rely on communication between involved stakeholders -from developer to end users-. In agile methodology, there are 4 activities that can be transformed for human resources management, those are:

1. Collection, doing inventory through out topics and materials that has role to human resource quality improvement.

2. Clustering, doing identification and grouping of the inventory results with the similarities, and sort them by priority.

3. Process, doing a set of activities in cluster items that is arranged as priority set before.

4. Release, implementation through training for employees run by the human resource department.

\section{Agile Methodology on Human Capital Development}

As discussed earlier, the agile methodology approach is adaptable to be transformed to other fields, including human resources performance and quality improvement [26], [27] The agile methodology is applicable to human resources in the era of IoT especially $Z$ generation that are very familiar with technology environment. The agile human resource management concept (area of competence: Personal Development - Leadership) described in detail in the following table 2.

To improve human resource quality to be ready to face millennium era, require a comprehensive, systematic, and direct management approach. The fulfillment of competence needed by organization personal must be well planned, so that skills owned can answer every opportunity challenged. Every organization personal must have competence like leadership skill, intra-personal skill, interpersonal skill, innovative, negotiation skill, communication skill, conflict management building, change management adaptation, business development, and so on.

\section{Conclusion}

This paper conclusion is that agile management used by software development conceptually transformable to the human resource development planning, so that may fulfill the needs of producing high talented human resources who has skill sets to compete in certain fields.

Developing agile human capital management hopefully become a new method or guidance, hence leaving behind classical way of study that is limited and rigid. With this agile method one can develop him self optimally without time and space limitation, or environment and even fund limitation. With that said, one may develop their competence in a comprehensive, systematic, and directed through agile methodology.

The authors suggests the production of a human resource competences road map to be used for improving the future organizational personal. 
Table 2. The Agile Human Capital Planning Management Concept (Competence: Personal Development - Leadership)

\begin{tabular}{|c|c|c|c|c|}
\hline $\begin{array}{l}\text { Area of } \\
\text { Compt. }\end{array}$ & Collection & Clustering & Process & Release \\
\hline \multicolumn{5}{|c|}{ Personal Development } \\
\hline $\begin{array}{l}1 . \\
\text { Leadership }\end{array}$ & $\begin{array}{l}\text { What Is Leadership? } \\
\text { - Leadership Skills } \\
\text { Training from } \\
\text { MindTools.com } \\
\text { https://www.mindtools. } \\
\text { com/leadership-skills } \\
\mathbf{8} \text { Essential Qualities } \\
\text { That Define Great } \\
\text { Leadership - Forbes } \\
\text { https://www.forbes.com/ } \\
\text { sites/.../02/.../8-essential- } \\
\text { qualities-that-define- } \\
\text { great-leadership/ } \\
\text { Harvard advanced } \\
\text { leadeship - Seeking } 43 \\
\text { Great Leaders. } \\
\text { http://www. } \\
\text { advancedleadership. } \\
\text { harvard.edu/leadership } \\
\text { Goleman's Leadership } \\
\text { Styles } \\
\text { https://youtu.be/ } \\
\text { vGPqfxAbwN4 } \\
\text { Situational Leadership } \\
\text { https://youtu.be/H1SiGs- } \\
\text { SVdA }\end{array}$ & $\begin{array}{l}\text { To group some type of leadership commonly } \\
\text { used in organizations: } \\
\text { 1. Coercive } \\
\text { - Suitable when fast decision making required } \\
\text { - Negative impact arise in long term usage } \\
\text { - Example: when problem arise with } \\
\text { employees } \\
\text { - Style in sentence: "Do as I said." } \\
\text { 2. Authoritative } \\
\text { - Leader mobilized subordinates toward } \\
\text { targeted vision } \\
\text { - Applicable when clear instruction needed. } \\
\text { - Style in sentence: "Come and follow me." } \\
\text { 3. Affiliative } \\
\text { - Leader creates harmony and strong emotion } \\
\text { bond with subordinates. } \\
\text { - Applicable to motivate employee under } \\
\text { stressful situation. } \\
\text { - Style in sentence: "Serving others first." } \\
\text { 4. Democratic } \\
\text { - Leader creates consensus through all team } \\
\text { members participation } \\
\text { - Applicable when input from valuable } \\
\text { employee needed } \\
\text { - Style in sentence: "What do you think?" } \\
\text { 5. Coaching } \\
\text { - Leader prepare team members for the future } \\
\text { - Applicable to increase employee } \\
\text { performance, or building long term power } \\
\text { - Style in sentence: “Try this way." } \\
\text { - Situational } \\
\text { - To leadership style that fit to all situations. } \\
\text { to certain condition. }\end{array}$ & $\begin{array}{l}\text { 1. Conducting group } \\
\text { simulation to } \\
\text { demonstrate each type } \\
\text { of leadership under } \\
\text { various scenario of } \\
\text { situation. } \\
\text { 2. All participants } \\
\text { observe other group } \\
\text { presentation's and } \\
\text { taking notes about the } \\
\text { positive and negative } \\
\text { points learned. } \\
\text { 3. Each group presenting } \\
\text { their observation of } \\
\text { other groups, and } \\
\text { include their own } \\
\text { group. } \\
\text { 4. Through simulation, } \\
\text { the participants gain } \\
\text { understanding or } \\
\text { skills to implement } \\
\text { leadership style } \\
\text { applicable in their own } \\
\text { area of work. } \\
\text { 5. Evaluation conducted } \\
\text { to polish up the } \\
\text { concept understanding } \\
\text { that is manifested } \\
\text { in the organization } \\
\text { environment, so that } \\
\text { it may contributed in } \\
\text { form of a new style } \\
\text { of leadership to future } \\
\text { leader community. }\end{array}$ & $\begin{array}{l}\text { Practical } \\
\text { implementation } \\
\text { for every style of } \\
\text { leadership learned, } \\
\text { the strength and the } \\
\text { weakness of each } \\
\text { style. }\end{array}$ \\
\hline
\end{tabular}

\section{References}

[1] R. Zemke, C. Raines, and B. Filipczak, Generations at work, Second. New York: AMACOM, 2013.

[2] R. N. Bolton et al., "Understanding Generation Y and their use of social media: A review and research agenda," J. Serv. Manag., vol. 24, no. 3, pp. 245267, 2013, doi: 10.1108/09564231311326987.

[3]A. Singh and J. Dangmei, "Understanding the Generation Z: the Future Workforce," no. April, pp. 1-6, 2016.

[4] Z. Kirchmayer and J. Fratričová, "On the verge of Generation Z: Career expectations of current university students," Proc. 29th Int. Bus. Inf. Manag. Assoc. Conf. - Educ. Excell. Innov. Manag. through Vis. 2020 From Reg. Dev. Sustain. to Glob. Econ. Growth, no. May, 2017.

[5] T. D. Baruah, "Effectiveness of Social Media as a tool of communication and its potential for technology enabled connections: A micro-level study," Int. J. Sci. Res. Publ., vol. 2, no. 1, pp. 1-10, 2012, doi: ISSN 2250-3153.

[6] S. Denef, N. Kaptein, P. S. Bayerl, and L. Ramirez, "Best Practice in Police Social Media Adaptation," Sankt Augustin, 2012.
[7] U. Gündüz, "The Effect of Social Media on Identity Construction," Mediterr. J. Soc. Sci., vol. 8, no. 5, pp. 85-92, 2017, doi: 10.1515/mjss-2017-0026.

[8] J. Mingle, M. Adams, and E. A. Adjei, “A Comparative Analysis of Social Media Usage and Academic Performance in Public and Private Senior High Schools," J. Educ. Pract., vol. 7, no. 7, pp. 13-22, 2016.

[9] E. Holm, "Social networking, the catalyst for identity thefts in the digital society," Int. J. Adv. Life Sci., vol. 6, no. 3-4, pp. 157-166, 2014.

[10] D. U. Patton et al., "Social media as a vector for youth violence: A review of the literature," Comput. Human Behav., vol. 35, pp. 548-553, 2014, doi: 10.1016/j.chb.2014.02.043.

[11] J. Kuzma, V. Bell, and C. Logue, "A Study of the Use of Social Media Marketing in the Football Industry.," J. Emerg. Trends Comput. Inf. Sci., vol. 5, no. 10, pp. 728-738, 2014.

[12] S. Zulhuda, "the Concept of Internet of Things and," South East Asia J. Contemp. Business, Econ. Law, vol. 8, no. December 2015, 2016. 
[13] S. Rajguru, S. Kinhekar, and S. Pati, "Analysis of Internet of Things in a Smart Environment," vol. 4, no. 4, pp. 40-43, 2015.

[14] T. Borgohain, U. Kumar, and S. Sanyal, "Survey of Security and Privacy Issues of Internet of Things," arXiv Prepr. arXiv1501.02211, p. 7, 2015, doi: 1501.02211.

[15] R. P. Pawar, "A Comparative study of Agile Software Development Methodology and traditional waterfall model," IOSR J. Comput. Eng., pp. 01-08, 2015.

[16] G. Ahmad, "Agile Methodologies: Comparative Study and Future Direction,” 2014.

[17] M. K. Levine, A Tale of Two Transformations Bringing Lean and Agile Software Development to Life, 1st ed., vol. 1. Florida: CRC Press, 2011.

[18] Y. Leau, W. Loo, W. Tham, and S. Tan, "Software Development Life Cycle AGILE vs Traditional Approaches," Int. Conf. Inf. Netw. Technol. (ICINT 2012), vol. 37, no. Icint, pp. 162-167, 2012.

[19] A. S. Denney and R. Tewksbury, "How to Write a Literature Review," J. Crim. Justice Educ., vol. 24, no. 2, pp. 218-234, 2013, doi: 10.1080/10511253.2012.730617.

[20] A. Henriksen and S. A. R. Pedersen, "A qualitative case study on Agile Practices And Project Success in agile software projects," J. Mod. Proj. Manag., vol. May, no. August, 2018, doi: 10.19255/JMPM01306.
[21] T. Silva et al., "User Experience Design and Agile Development : From Theory to Practice," J. Softw. Eng. Appl., vol. 5, no. October, pp. 743-751, 2012, doi: $10.4236 /$ jsea.2012.510087.

[22] V. Lalsing, S. Kishnah, and S. Pudaruth, "People Factors In Agile Software Development And Project Management," Int. J. Softw. Eng. Appl., vol. 3, no. 1, pp. 117-137, 2012, doi: 10.5121/ijsea.2012.3109.

[23] G. M. Kapitsaki and M. Christou, "Learning from the Current Status of Agile Adoption," Eval. Nov. Approaches to Softw. Eng., vol. 551, pp. 18-32, 2015, doi: 10.1007/978-3-319-27218-4.

[24] P. A. Adeyemi and A. J. Ogunsola, "The Impact of Human Capital Development on Economic Growth in Nigeria : ARDLApproach," J. Humanit. Soc. Sci., vol. 21, no. 3, pp. 1-7, 2016, doi: 10.9790/08372103040107.

[25] I. Šlaus and G. Jacobs, "Human Capital and Sustainability," Sustainability, pp. 97-154, 2011, doi: 10.3390/su3010097.

[26] R. Alami et al., "The Effectiveness of Human Resource Management on Improving the Performance," Int. J. Bus. Soc. Sci., vol. 6, no. 5, pp. 251-254, 2015.

[27] M. Hamid, S. Maheen, A. Cheem, and R. Yaseen, "Impact of Human Resource Management on Organizational Performance," J. Account. Mark., vol. 06, no. 01, pp. 1-7, 2017, doi: 10.4172/21689601.1000213. 